\title{
Sobre las canciones femeninas de la Edad Media española*
}

\section{About Feminine Songs of the Spanish Middle Ages}

\author{
MARgit Frenk \\ Universidad Nacional Autónoma de México \\ margitfrenk@gmail.com
}

Se analizan las características de la lírica popular en voz femenina, particularmente se abordan las tendencias que se observan en relación con el espacio y con el cuerpo, lo que permite extraer una conclusión.

Palabras Clave: lírica popular medieval, literatura en voz femenina, mujer medieval, espacio y cuerpo femeninos

The characteristics of the popular lyric in the female voice are analyzed, particularly the tendencies observed in relation to the space and the body, which allows to draw a conclusion.

KEYWORDS: medieval popular lyrics, literature in female voice, medieval woman, female space and body

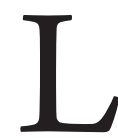

a lírica popular de la España medieval revela un mundo imaginativo muy peculiar, distinto de cuanto lo rodea en el tiempo y el espacio. Los cantarcillos que durante siglos, antes de que fueran puestos por escrito en el Renacimiento, entretuvieron a la gente humilde mientras trabajaba y mientras descansaba, dejan entrever ciertas formas de sensibilidad, ciertas maneras especiales de sentir el mundo, que contrastan fuertemente con las de la lírica aristocrática contemporánea.

Coincido con quienes consideran como factor fundamental de la cultura popular su contraste, deliberado o no, con la cultura oficial y dominante.

* Resumo aquí una parte de una ponencia plenaria presentada en el III Congreso Internacional de la Asociación Hispánica de Literatura Medieval, celebrado en Salamanca, en octubre de 1989. 
Ante esta, que se considera a sí misma como la única válida, autorizada, universal, la cultura popular resulta "contestataria", en el sentido de que le contrapone un sistema distinto $y$, hasta cierto punto, autónomo. ${ }^{1}$

Entre la lírica popular hispánica de la Edad Media y la poesía aristocrática contemporánea el rasgo diferenciador más notable y asombroso es, sin duda, la presencia, en la primera, de la voz femenina. Se trata, por cierto, de un hecho no exclusivo de la Península ibérica. ${ }^{2}$ Esa voz de mujer se contrapone a la voz de hombre que monopoliza la lírica cortesana paneuropea; esa voz expresa una serie de actitudes que, a la luz de las leyes y normas que rigen a la sociedad de entonces, resultan anómalas o incluso francamente subversivas.

Investigaciones recientes han revelado cosas interesantes sobre las leyes y normas de la España medieval en lo que se refiere a las mujeres humildes. Sabemos - y aquí no puedo sino hablar a grandes rasgos - que las campesinas participaban activamente en los trabajos del campo y que solían intervenir en ciertas artesanías y en el pequeño comercio. Este papel que desempeñaban en la producción, ${ }^{3}$ esta contribución a la economía familiar, y las exigencias mismas de las actividades que realizaban, daban a las mujeres del pueblo una cierta libertad de la que no gozaban las pertenecientes a las clases superiores. ${ }^{4}$

${ }^{1}$ Cf. L. M. Lombardi Satríani: "ya con su sola existencia, $[\ldots]$ los valores folklóricos muestran los límites de la universalidad de los valores 'oficiales”" - (Apropiación y destrucción de la cultura de las clases subalternas. trad. E. Molina, México: Nueva Imagen, 1978, p. 28; cf. pp. 18-22, passim.).

${ }^{2}$ Sobre esto es muchísimo lo que se ha escrito; remito a la bibliografía citada en mi libro Las jarchas mozárabes y los comienzos de la lírica románica. 1a. reimpr., México: El Colegio de México, 1985, en especial, pp. 78 - 82, y al libro de Ria Lemaire, Passions et positions. Contribution à une sémiotique du sujet dans la poésie lyrique médiévale en langues romanes. Amsterdam: Rodopi, 1987.

${ }^{3}$ Cf. Alexandra Kollontai, Mujer, historia y sociedad. Sobre la liberación de la mujer, Barcelona: Fontamara, 1982, p. 107; "En todos los periodos remotos del desarrollo económico, el papel de la mujer en la sociedad y sus derechos dependían de su posición en la producción”. Cf. Eileen Power, Mujeres medievales, trad. C. Graves, Madrid: Ediciones Encuentro, 1979; Régine Pernoud, La mujer en el tiempo de las catedrales, trad. Marta Vasallo, Buenos Aires: Granica, 1987; Mercedes Borrero Fernández, "El trabajo de la mujer en el mundo rural sevillano durante la baja Edad Media”, en Las mujeres medievales y su ámbito jurídico. Actas de las II Jornadas de Investigación Interdisciplinaria. Madrid: Seminario de Estudios de la Mujer y Universidad Autónoma, 1984, pp. 191-199.

${ }^{4}$ Sobre todo esto, véase, para el Occidente medieval, A. Kollontai, op. cit., pp. 91-106. Para la Península ibérica: Cristina Segura, Las mujeres en el medievo hispano, Madrid: Marcial Pons, 1984 (Cuadernos de Investigación Medieval, 1), principalmente pp. 36, 40 - 41; varios estudios en Las mujeres en las ciudades medievales. Actas de las III Jornadas de investigación interdisciplinaria sobre la mujer, Madrid, 1984 (por ejemplo, el de A. Domínguez Ortiz); otros, 
Al mismo tiempo, se trataba de una libertad limitada, decididamente muy inferior a la que tenían los hombres del mismo estrato social. En el seno de la familia las mujeres solteras estaban supeditadas al padre; las casadas, al marido. ${ }^{5}$ La mujer casada gozaba de más estima que la soltera, ${ }^{6}$ la cual, a diferencia de la viuda, de ningún modo podía vivir sin un hombre al lado; ${ }^{7}$ si lo hacía, se la consideraba mujer no honrada.

Algunas de estas cosas se ven confirmadas en la lírica popular; por ejemplo, la participación de las mujeres en la agricultura y el pastoreo, sus actividades artesanales y comerciales. Otros aspectos de la lírica femenina parecerían remontarse a realidades de épocas muy anteriores, como la escasa presencia del padre y la omnipresencia de la madre. Y también tiene la poesía femenina facetas que diríamos relacionadas "por antítesis" con la realidad social contemporánea; entre ellas, el protagonismo de la muchacha soltera, a la cual la literatura popular le concede lo que la vida le niega; presencia, relieve $y$, ante todo, voz. Es esta una voz que nos dice mucho acerca de la mentalidad soterrada de las aldeanas y campesinas de la España medieval; nos dice mucho, en un nivel profundo, de cómo vivían la vida que les había tocado en suerte.

En relación con esto, vale la pena observar la concepción del espacio y del cuerpo que revelan las cancioncillas femeninas de la Edad Media española. Me parece ver en ellas dos tendencias o visiones contrapuestas. ${ }^{8}$ Por una parte hay un espacio virtualmente cerrado, dentro del cual la mujer está inmóvil; por otr[a], lo contrario: el espacio abierto y un incesante movimiento. En medio de esos dos ámbitos opuestos, un espacio "puente" que los enlaza.

en el citado libro Las mujeres medievales y su ámbito jurídico..., y, en La condición de la mujer en la Edad Media. Actas del Coloquio celebrado en la Casa de Velázquez ... 1984, Madrid: Casa de Velázquez y Universidad Complutense, 1986.

${ }^{5}$ Cf. A. Kollontai, op. cit., p. 93; C. Segura, op. cit., p. 16.

${ }^{6} \mathrm{Cf}$. Heath Dillard, "Women in Reconquest Castile: The Fueros of Sepúlveda and Cuenca", en S. Mosher Stuard (ed.), Women in Medieval Society. [Philadelphia]: The University of Pennsylvania Press, 1976, p. 85.

${ }^{7}$ Cf. C. Segura, "Situación jurídica y realidad social de casadas y viudas en el medioevo hispano (Andalucía)", en La condición de la mujer, op. cit., pp. 123,125, y su trabajo en Las mujeres medievales, op. cit., p. 33.

${ }^{8} \mathrm{Cf}$. el interesante artículo de Consuelo Arias, "El espacio femenino en tres obras del medioevo español; de la reclusión a la transgresión”, La Torre. Revista de la Universidad de Puerto. Nueva época, 1 (1987), pp. 365-388. Estudia el espacio de la mujer en el Poema del Mio Cid ("el lugar cerrado y protegido", p. 369) y en el Libro de Buen Amor y La Celestina ("apertura del espacio interior femenino a los elementos exteriores, masculinos y mundanos", apertura vista como "transgresión de la norma social", loc. cit.).

Medievalia 50, 2018, pp. 5-11 
Buen número de canciones muestran a la muchacha esperando, pasiva, ${ }^{9}$ en un lugar no especificado que obviamente es la casa:

$$
\begin{aligned}
& \text { Si la noche hace escura, } \\
& \text { y tan corto es el camino, } \\
& \text { ¿cómo no venís, amigo? }{ }^{10}
\end{aligned}
$$

Hay también la invitación, dulce o imperativa, hecha desde la casa: "Al alba venid, buen amigo, / al alba venid" (452). Es la joven encerrada, cautiva, como nos la pintan la literatura y tantos textos sobre la mujer en la Edad Media.

En el otro extremo, mucho más representado en este conjunto poético, está la muchacha al aire libre, trabajando u ociosa, en el campo, en la tierra de cultivo, la huerta, el monte, la sierra, la peña, a las orillas del mar o del río, junto a la fuente, en la aldea o la villa, en la calle. ${ }^{11} \mathrm{Y}$ esa muchacha es presentada en continuo movimiento.

En el monte anda la niña...

Por aquí, por aquí, por allí, anda la niña en el toronjil... (1486)

¿Adónde tan de mañana, hermosa serrana? (1000)

Es sobre todo ella la que continuamente se muestra a sí misma en movimiento:

Yo me iba, mi madre

a la romería... (313)

${ }^{9} \mathrm{Cf}$. C. Arias, art. cit.: en el Poema del Mio Cid, "la función de los personajes femeninos es fundamentalmente la espera, actividad pasiva por excelencia..." (p. 373).

${ }^{10} \mathrm{Cf}$. mi Corpus de la antigua lírica popular hispánica, Madrid: Castalia, 1987, no. 573. A esta obra remiten en adelante los números entre paréntesis.

${ }^{11}$ Algunos ejemplos: "En el campo de la galana ... vi" (74), "En la huerta ... /quiérome ir allá" (8), "entré en la siega" (137), "la moça guardava la viña" (7), "guardando el ganado/ la color perdi" (139), "Ribera de un río / vi moça virgo" (353 B), "En la peña ... duerme la niña..." (19), "Criéme en aldea" (141), "Dícenme que tengo amiga / de dentro de aquesta villa" (67), "No me habléis, conde, / d' amor en la calle / catá que os dira[]mal,/ conde, la mi medre. / /Mañana yré, conde, / a lavar al río;/ allá me tenéis, conde, / a vuestro servicio." (390). Alguna vez aparece la mujer en el espacio urbano: "De los álamos de Sevilla, / de ver a mi linda amiga" (309 B), "Fátima ... levaros he a Sevilla" (458), "Tres morillas ... / en Jaén" (16 B), "Moças de Toledo" (896). 
Yéndome y viniendo

a las mis vacas... (1645 B)

Ibame yo, mi madre

[ ] a vender pan a la villa... (120 B)

A menudo el movimiento es de retorno: "Viniendo de la romería" (273 A), "Del amor vengo yo presa" (270), "Del rosal vengo, mi madre"(306). O sea, la muchacha sale, camina, pero después regresa a su centro, a casa.

Desde ahí, cuando está encerrada, construye eso que he llamado un "puente" hacia el exterior: la niña mira la puerta, piensa en ella (y en el hombre que va a pasar por ahí):

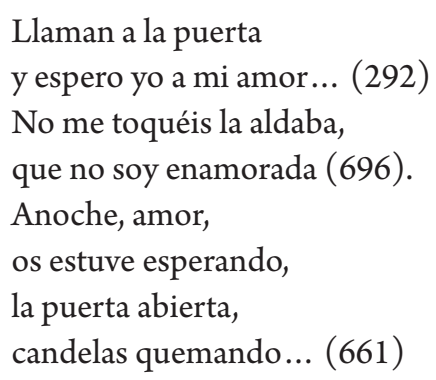

Es interesante ver que en el espacio simbólico del cuerpo femenino hay un elemento que equivale a la puerta: los ojos.

Aparte de constituir el centro de la belleza - "Mis ojuelos, madre, / valen una ciudade” (128) - son el vehículo por el cual la mujer expresa su amor o su desamor "Por una vez que mis ojos alcé, / dizen que yo le maté" (185 C)-, y, desde luego, la puerta por la que sale y entra el deseo:

Quando le veo el amor, madre, toda se arrebuelve la mi sangre (290)

Debemos preguntamos por qué el cancionero popular nos presenta imágenes contradictorias del espacio femenino. Quizá sea precisamente la imagen intermedia, ese estar entre el adentro y el afuera y entre la inmovilidad y el movimiento, lo que nos dé la clave y posibilite una interpretación tentativa.

Volvamos a lo que dice la historia sobre la situación de la mujer campesina en la Edad Media. A lo que sabemos hay que añadir que entre la población humilde del campo rigen normas morales más rigurosas que las de la 
ciudad. ${ }^{12}$ La mujer campesina, entonces, salía a trabajar; y al mismo tiempo estaría bajo la vigilancia y el control férreo del padre, de los hermanos, del marido. La libertad de la mujer campesina no sería, en realidad, más que una relativa libertad de movimiento, justo la necesaria para que pudiera contribuir al mantenimiento de la familia. Posiblemente esa relativa libertad hiciera más aguda la vivencia del sometimiento. Si en sus canciones la campesina española se sitúa en un espacio ambiguo, acaso este constituya un correlato de su ambivalente situación en la vida cotidiana. Pero habría que dar un paso más: puesto que, en el fondo, la mujer real está atada, serían las imágenes poéticas de encerramiento las que verdaderamente corresponderían en el plano imaginativo a su realidad, mientras que las imágenes, mucho más frecuentes, de libertad, aunque propicias por sus ires y venires en la vida diaria, se situarían en el ámbito de sus deseos, de sus sueños y sus fantasias.

Es este el ámbito en el que parecen ubicarse, de hecho, la mayoría de los cantares femeninos hispánicos. En ellos la muchacha expresa, no solo su libertad física, sino también su independencia. Se muestra dueña absoluta de su vida y ejerce, gozosamente, su voluntad. Frente a la familia que la vigila y la reprime, la joven no se cansa de exclamar en tono jubiloso:

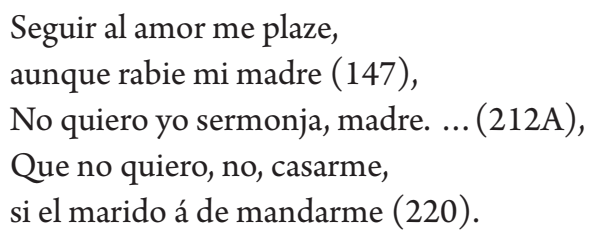

Reiteradamente, el "no quiero" y la franca rebeldía contra el sometimiento y la clausura. Incluso la casada tiene, en esa poesía, la posibilidad de lberarse, a través del adulterio. El ferviente afán de libertad va asociado en la mujer, soltera o casada, al deseo de amar a su antojo: "No quiero ser casada, / sino libre enamorada (216)", "Que non dormiré sola, non, / sola y sin amor" (168). Y cuando todo indica que "en materia sexual, al menos en público, la iniciativa pertenece a los hombres", ${ }^{13}$ en el cancionero es ella la que las más veces pide a su amado que se la lleve:

${ }^{12}$ Cf. Amours légitimes, op. cit., p. 101 (C. Larquié, en la discusión). C. Arias, art. cit., p. 377: "En el Libro de buen amor y en La Celestina [... ] se modela un mundo cuya organización social es relativamente libre y permisiva $[. .$.$] . La ciudad proporciona posibilidades de movimiento$ que no existen en la sociedad rural. Por ejemplo, la visita, el mercado, la vida callejera y el vivir en cierta proximidad facilitan nuevas formas de relaciones interpersonales".

${ }^{13} \mathrm{~J}$. - P. Dedieu, en B. Benassar, Inquisición española: poder político y control social, trad. J. Alfaya, Barcelona: Crítica, 1981, p. 285. 
Por el río me llevad, amigo,

y llevádeme por el río. ${ }^{14}$

¿Proyecciones del deseo, sueños de mujer, pocas veces realizables? En el Auto X de la Celestina se queja Melibea: “¿Por qué no fue también a las hembras concedido poder descubrir su congojoso y ardiente amor, como a los varones?"15 Las mujeres de la lírica popular sí declaran, y sin ambajes, su ardiente amor. ¿Es que había una gran diferencia entre las posibilidades de la muchacha humilde y las de la mujer encumbrada? Más bien pienso que la campesina, al cantar, rebasaba continuamente, gozosamente, los límites de su realidad.

\footnotetext{
${ }^{14}$ A la luz de estos cantares ( $c f$. también los números 464, 469), habría que matizar las siguientes afirmaciones de Consuelo Arias, art. cit., p. 383: "Quizá la dimensión más innovadora de La Celestina es la subversión de los códigos de comportamiento femenino. Se da una versión del paradigm actividad - masculinidad / pasividad - feminidad. [...] Los personajes femeninos son los que manipulan, actúan y controlan el destino y las acciones de los personajes masculinos. [...] Aquí surge un contraste marcado entre la concepción de la mujer en $L C$ y en la épica y lírica medievales" (subrayado mío). Como hemos visto, también ese "otro elemento no - convencional de Melibea" (ibid., p. 387) que es su afirmación del placer y su rechazo del matrimonio - "más vale ser buena amiga que mal casada" - tiene un correlato en los personajes femeninos de la lírica popular contemporánea y anterior.

${ }^{15}$ La Celestina, ed. D. S. Severin, Madrid: Alianza Editorial, 1981, p. 154.
}

Medievalia 50, 2018, pp. 5-11 
